\title{
Optimization of Gobak Sodor Based Neuroscience Learning Game as Character Education in Intellectual Disabilities
}

\author{
Ida Ayu Dian Pramantik \\ Sekolah Luar Biasa (SLB) Negeri 1 Bantul, D.I. Yogyakarta \\ idayudianp@gmail.com
}

\begin{abstract}
The purpose of writing this article is to find out the optimization of traditional gobak sodor neuroscience learning-based game activities as character education in intellectual disability with grade medium (ATG). Referring to the problems, most schools do not have policies and administrations regarding character education, most schools that have an environment that supports the implementation of character education, most teachers do not have good knowledge and attitude in character education, most teachers do not have good competence, most schools have used the curriculum and most teachers have not used assessments that are suitable for children. Character education and most of the community has not supported the course of character education. The purpose of writing this article is to find out the optimization of traditional "gobak sodor" neuroscience learning-based game activities as character education in children ATG. The method used in writing this article is the study of non-systematic literature from national \& international database. Based on the concept of a previous relevant frame of mind, schema, and research, it can be concluded that there will be optimization of traditional "gobak sodor" game activities based on neuroscience learning as character education in children. Optimization of adaptive physical education learning can occur through synergistic contributions through neuroscience learning in traditional games and character education of lightly impaired children. The results of adaptation of these mechanisms are able to reduce the barriers of cognitive domains, practice domains, and social domains of lightly impaired children.
\end{abstract}

Keywords: character, neuroscience learning, traditional games, ATG

\begin{abstract}
Abstrak
Tujuan penulisan artikel ini adalah untuk mengetahui optimalisasi kegiatan permainan berbasis neuroscience learning "gobak sodor" tradisional sebagai pendidikan karakter dalam disabilitas intelektual dengan kelas menengah (ATG). Mengacu pada masalah, sebagian besar sekolah tidak memiliki kebijakan dan administrasi mengenai pendidikan karakter, sebagian besar sekolah yang memiliki lingkungan yang mendukung pelaksanaan pendidikan karakter, sebagian besar guru tidak memiliki pengetahuan yang baik.Pendidikan karakter dan sebagian besar masyarakat belum mendukung jalannya pendidikan karakter. Tujuan penulisan artikel ini adalah untuk mengetahui optimalisasi kegiatan permainan berbasis pembelajaran ilmu saraf "gobak sodor" tradisional sebagai pendidikan karakter pada anak ATG. Metode yang digunakan dalam menulis artikel ini adalah studi literatur non-sistematis dari database nasional \& internasional.
\end{abstract}


Sports Education Study Program, University of Ma'arif Nahdlatul Ulama Kebumen

Berdasarkan konsep kerangka pikiran, skema, dan penelitian yang relevan sebelumnya, dapat disimpulkan bahwa akan ada optimalisasi kegiatan permainan "gobak sodor" tradisional berdasarkan pembelajaran ilmu saraf sebagai pendidikan karakter pada anak-anak. Optimalisasi pembelajaran pendidikan jasmani adaptif dapat terjadi melalui kontribusi sinergis melalui pembelajaran ilmu saraf dalam permainan tradisional dan pendidikan karakter anak-anak yang mengalami gangguan ringan. Hasil adaptasi dari mekanisme ini mampu mengurangi hambatan domain kognitif, domain praktik, dan domain sosial anak ATG.

Kata Kunci: karakter, neuroscience learning, permainan tradisional, tunagrahita ringan

\section{Introduction}

Basically, the essence of education is to shape the character of a nation. It is largely determined by the spirit, motivation, values, and goals of education. When formulated, then the nature of education that is able to form the character of the nation (civilized). Education is a tip in applying the principles of science and technology to the formation of human beings completely (Mahmood, 2021; Mustofa, Mansur, \& Burhaein, 2019; Prasetyo Widiyono \& Mudiono, 2021). In education there is a process of human interaction that is characterized by a balance between the sovereignty of the subject of the learner and the authority of the educator. Education in principle lasts a lifetime. Education is an effort to prepare the subject of the learner to meet the environment that is experiencing greater changes. Education improves the quality of personal and community life (Ferdy Irawan \& Limanto, 2021; Molbaek, 2018; Phytanza \& Burhaein, 2020).

Character education today is important to instill in schools, not only for regular children but also children with disabilities. As is known, one of the disabilities is a intellectual disability (ATG) child. The children with ATG as well as on the domain of concept, social, and practice (American Psychiatric Association, 2013; Burhaein, Phytanza, \& Demirci, 2020). These obstacles need to be overcome by the right environment and learning concepts so as to increase the obstacles and basic abilities of children. To achieve the need for an active and stimulating learning environment for children, especially for the development of neurological networks of the child's brain, because it will be able to improve the child's abilities (Burhaein, Tarigan, Budiana, Hendrayana, \& Phytanza, 2021; Guntur Sutopo \& Misno, 2021).

Parents and teachers' ignorance of child brain science (neurobiology) has led to mistakes in early childhood education. As a result, natural potential cannot develop properly. Therefore, it is appropriate for teachers and parents to understand the work and natural development of the brain in children (Hielkema \& Hadders-Algra, 2016; Pramantik \& Burhaein, 2019; Rizqi Azizah $\&$ Pujo Sudarto, 2021). This knowledge, teachers and parents can provide effort to stimulate the development of the child's brain so that its natural function grows and develops.

The impact that occurs in children when addicted to playing games that results in the character who will wake up in the child. In addition, this paper also compares the influence of modern games with traditional games on the formation of child characters (Burhaein, 2017a; Phytanza, Burhaein, \& Pavlovic, 2021; Widodo \& Najibuzzamzam, 2021). Restoring traditional 
children's play as a child's game today can be an alternative to creating a generation of superior character.

From the results of previous research, it is obtained the picture that most schools do not have policies and administration regarding character education, most schools that have an environment that supports the implementation of character education, most teachers do not have good knowledge and attitude in character education, most teachers do not have good competence, Most schools have used curricula and most teachers have not used assessments suitable for character education and most communities have not supported the course of character education (Lonto, 2019; Suherman, 2018)

The purpose of writing this article is to find out the optimization of traditional game activities "gobak sodor" based on neuroscience learning as character education in ATG children. Based on the problems and purposes of writing above, the scope of this article is to explore the theoretically revealing / reviewing of traditional game activities "gobak sodor" based on neuroscience learning as character education in ATG children.

\section{Research Methodology}

The methodology used in the writing of this article is the study of literature. Literature studies are the study of non-research scientific writing. Then the approach in the study of literatu there are two, namely systematic and non-systematic. The author uses a non-systematic approach in this review literature. Non-systematic approach by collecting references related to themes without using certain criteria and analysis in exploring the study of problems to be revealed (Burhaein, Demirci, Lourenço, Németh, \& Phytanza, 2021; Fraenkel, Wallen, \& Hyun, 2012) The literature obtained is presented in the form of theoretical subtitles in the results section, then analyzed more in-depth in the discussion section.

\section{Results and Discussion}

\subsection{Results}

Based on the search results of literature articles that have been obtained from Google Scholar and other reputation database sources, it is made in the form of theoretical subtitles. This subheading summarizes the literature grouped so as to form an in-depth study.

\subsubsection{ATG Children}

Kauffman \& Hallahan (2011) defines ATG is a child with intelligence (IQ) below 70 who also has limitations on mental development, self-adjustment, and social. Characteristics in general of deaf children or known as intellectual disability disorder (IDD) according to Wardani, et.al. (2007: 35) says there are some characteristics 1) slow in learning new or foreign things according to him, 2) will always quickly forget what he has learned, 3) in speaking very less, 4) his movement and physical development are very lacking, and 5) less able to take care of himself, etc. Grouping of visually impaired children is not only based on IQ, because measurements based on IQ are less valid so that groupings based on conceptual domains, social domains, and practice domains. 
ATG children have barriers in the conceptual, social, and practical domains. The American Psychiatric Association (2013) describes the three domains for the mild category of blindness as follows:

a. Conceptual Domain

Children with mild category blindness at school age have learning difficulties in academic fields such as reading, writing, arithmetic, time management, and money management.

b. Social Domain

Children with mild categories of tunagrahita have different social conditions to ordinary children at their age because children lack maturity in social interactions. Children have difficulty understanding the instructions of their friends or teachers. Communication, conversation, language are more concrete and simple because they have not reached maturity according to their age. Children have difficulty organizing self-emotions and behaviors including in dressing according to their biological age. Children have difficulty getting peer attention due to limited understanding of social situations. This social realm gives rise to the nature of patience, orderly, responsibility, caring for others, obedient, diligent, lazy, selfish, easily discouraged, and rude.

c. Practice Domain

Children who are lightly impaired are required to have age-appropriate functions on their own personal care. To achieve these targets, children need some help coping with complex tasks at school or at home, compared to children their age who tend to be more independent.

\subsubsection{Character Education}

Character is a characteristic good value (knowing the value of kindness, willing to do good, real good living, and good life to the environment) that is imprinted in and manifested in behavior. Character education is the process of changing the nature, psyche, morals, ethics of a person or group of people in order to become adults (full human beings). Character education is essentially aimed at forming a nation that is tough, competitive, noble, moral, tolerable, royong, patriotic, dynamic-developed, science-oriented and technologically oriented all of which are imbued with faith and piety to God Almighty based on Pancasila (Bidaya \& Rangga, 2019; Lonto, 2019).

Character education can be interpreted as value education, ethical education, moral education, character education, which aims to develop students' ability to give good bad decisions, maintain good, create and spread goodness in everyday life wholeheartedly. According to the Ministry of Education (Kemendikbud RI, 2016) the development of character values in education has now been crystallized into five characters, namely religious, nationalist, integrity, independent, and gotong-royong. 


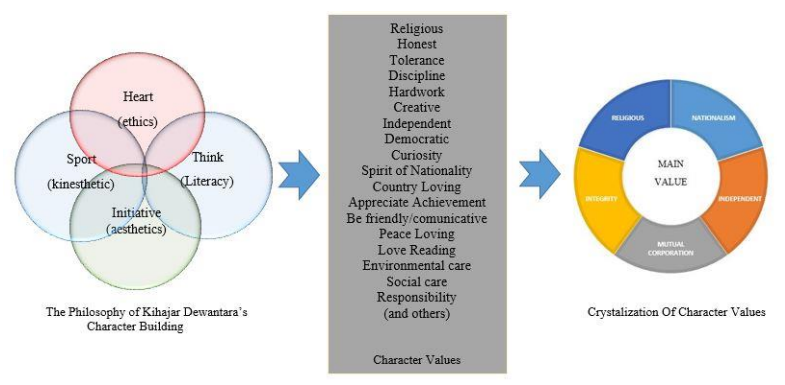

Figure 1. Character Values Development

(Kemendikbud RI, 2016)

\subsubsection{Traditional Games}

Saputri \& Suharjana (2020) explains that to increase the potential of children is to play. One game that can be used in early childhood play is a traditional game, because traditional games contain many elements of benefits and preparation for children living a community life. The benefits of traditional games in shaping children's character include: honesty, sportsmanship, persistence and royongan. With traditional games children can practice concentration, knowledge, attitude, skill and dexterity that are purely done by the human brain and body. In addition, traditional games can also develop aspects of moral development, religious values, social, language, and motor function. Furthermore, (Burhaein, 2017b) explains that traditional games applied in physical education sessions are suitable for improving motor skills and character in students. In particular, traditional games in the Special Region of Yogyakarta and Central Java are allegedly still potentially sustainable (awake) in the community including, gasing, egrang, gobak sodor, catfish patok, rounders, mushrooms, and cublak-cublak suweng.

\subsubsection{Neuroscience Learning}

Fitri (2017) explain metacognitif in the learning process of children in relation to neuroscience, as follows:

a. Emotional control

In fact, the frontal lobe as a rational system as a sophisticated brain to regulate thinking skills if often used then the brain's work is increasingly sophisticated. The role of the frontal lobe (thinking brain) is strongly influenced by the amygdala (emotion control). Positive emotions, such as joy, cause the frontal lobe (thinking brain) to work optimally and be ready to do higher cognitive work. Instead negative emotions such as sadness, fear cause the frontal lobe (thinking brain) to not work. For the sake of learning, teachers must coordinate children's emotions so that in a happy emotional atmosphere before starting the lesson so that the child's thinking skills can work optimally.

\section{b. Cognitive control}

The cognitive brain and the emotional brain support each other. In the process of learning early childhood not only uses the processing of subject matter cognitively but also describes the mind emotively.

c. Motor Control 
Motor development is the ability to move, both fine motor movement (squeezing, grasping) and gross motor (crawling, walking). Motor skills involve the cooperation of complex neural networks. This includes integrating balance sensors located in the inner ear, as well as output signals sent through the muscles of the hands and feet in the form of external stimulation.

(Guyton \& Hall, 2017; Kothari \& Sharma, 2019) explained that neuroscience has several dimensions of neuroscience, among others:

1) The scope of cellular-molecular study, it studies a wide variety of nerve cells and how they perform specific functions that differ from one another to produce a variety of complex behaviors, such as emotions, cognition, and action.

2) The nervous system examines the same functioning nerve cells in a complex system.

3) Behavioral neurosciences examine the various nervous systems working as mentioned above working together to produce certain behaviors. This field studies how the human "social brain" plays a role in helping humans form relationships with others.

4) The ability of humans to connect with others.

Learning strategies that can optimize education in children, namely through neural-based neuroscience learning in the brain with principles such as below:

1) Creating a learning environment that can make children engrossed in the learning experience, namely by involving all physiological aspects of children.

2) Provide diverse learning opportunities in the classroom.

3) Create an active learning environment.

4) Create a learning atmosphere that is free of pressure and threats but still challenging for children to find out more.

5) Create a curriculum that can foster children's interests and contextuals so that children can capture the meaning or meaning of what they learn.

6) Provide subjects by involving concrete experience, especially in problem solving, because the learning process is most effective not with lectures, but by being given real experience.

Neuroscience learning offers an alternative to the development of the potential of learning's intelligence linguistically and logically through gestures, spiritual, physical, interpersonal, naturalist, and existential. Neuroscience learning is combined with various disciplines so that it is integrated and becomes mainstream character formation (Erniati, 2015). Neuroscience learning in learning has effects on emotions, memory, decision making, cognitive, motor, creativity, and culture.

The neuroscience learning approach, experiencing rapid development in educational practice. Today, the practice of such approaches consists of five dimensions. According to (Schunk, 2014), the educational practice of neuroscience learning approaches includes: (1) problem-based learning; (2) simulations and role-playing; (3) active discussion; (4) visual display; and (5) a positive climate.

\subsection{Discussions}

Game activities are included in the subjects of Physical Education. There are four areas in physical education. (Joyce, Weil, \& Calhoun, 2015; Metzler, 2017) sports physical education is divided into 4 domains namely cognitive, psychomotor, affective, and healthy and fit behaviors. For visually impaired children, adaptive physical education needs to be adjusted to 
the child's obstacles, namely in three domains: conceptual domain, practice domain, and social domain. Schunk's Neuroscience learning approach (Schunk, 2014), is expected to be able to optimize the domain of deaf children through adaptive physical education in the form of sodor gobak games. The cognitive aspect as a center not only optimizes the child's cognition, but is also able to improve movement, improve the child's character, and motivate children to routinely perform physical activity.

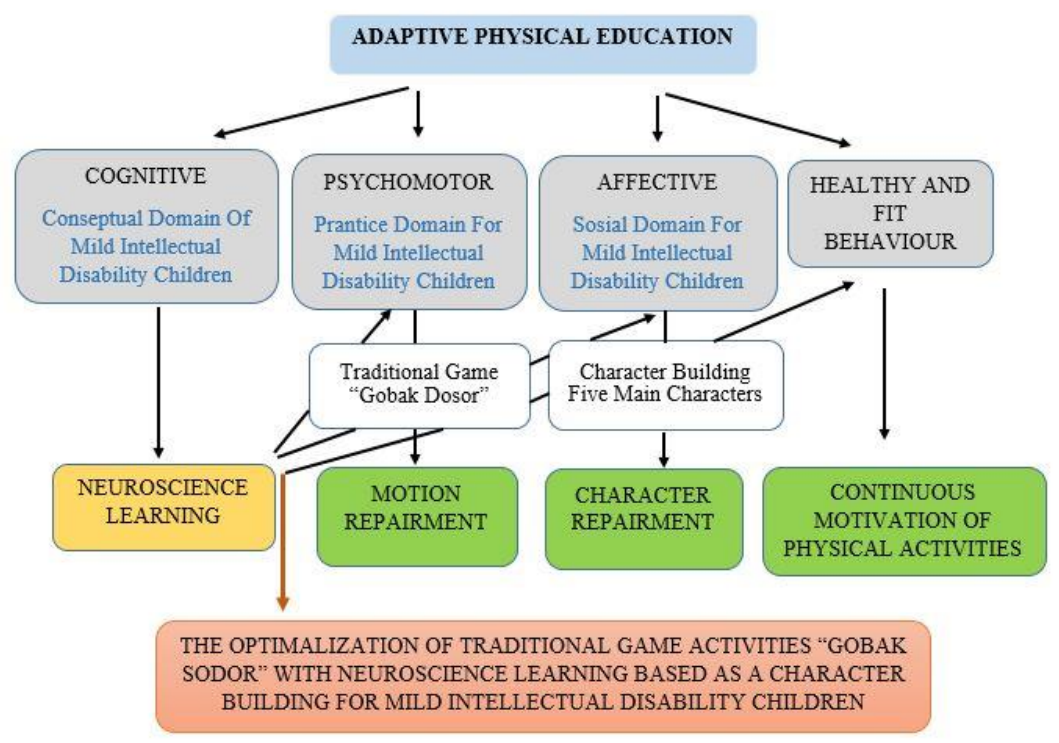

Source: Author of Burhaein (2017b)

Figure 2. Chart optimization of traditional "gobak sodor" neuroscience-based learning game activities as character education on ATG children

The Neuroscience Learning scheme and character education in the traditional game "Gobak Sodor", are described as figures 3 and 4:

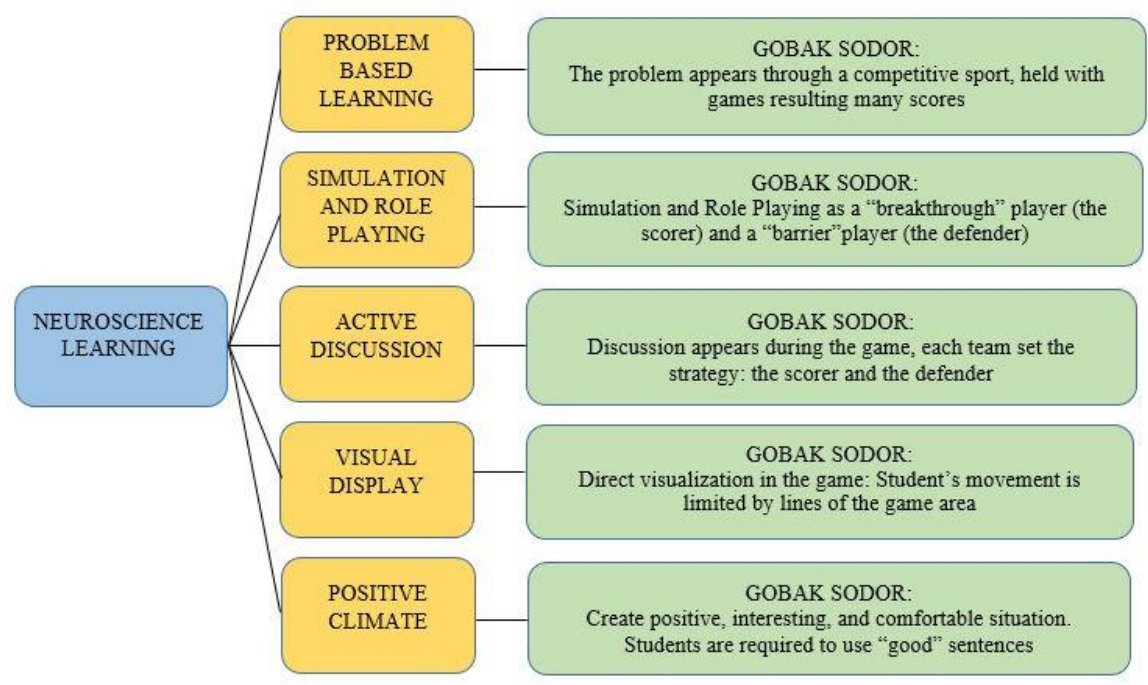

Source: Burhaein (2017b)

Figure 3. Neuroscience Learning Scheme on the traditional game "Gobak Sodor" 
Sports Education Study Program, University of Ma'arif Nahdlatul Ulama Kebumen

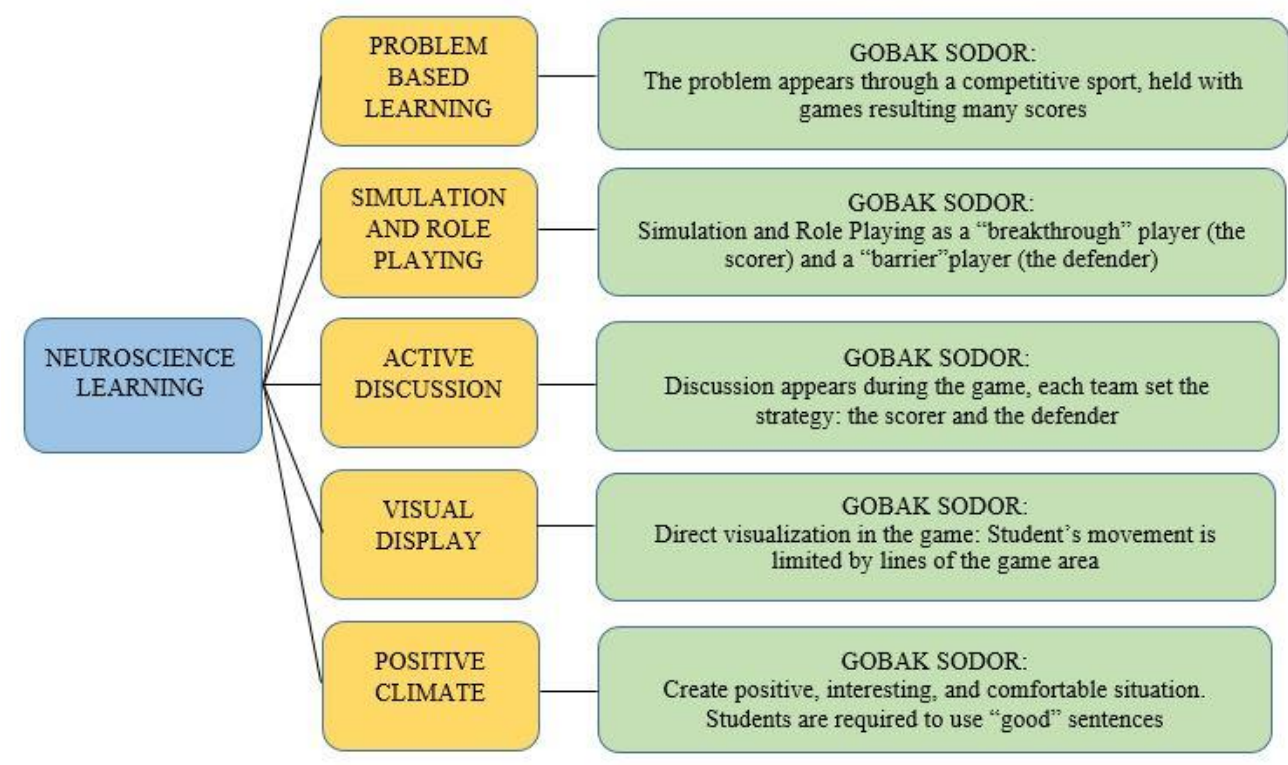

Source: Burhaein (2017b)

Figure 4. Character Education Scheme on the traditional game "Gobak Sodor"

The above discussion mechanism is also strengthened by previous studies related to traditional game activities "gobak sodor" through neuroscience learning as character education in ATG children:

a. Hendrowibowo (2018) concluded that traditional games are one of the means of character education that refers to aspects of child development related to cognitive, language, art, emotions, social, and noble values of the nation. Thus aspects of academic and social intelligence, mental / psychological children always improve and make children become full human beings to a certain degree.

b. Irman (2017) on the values of characters in children in traditional and modern games concludes: (1) Traditional games generally use natural game tools and where the game is done in the open, while modern games use electronic tools, and are generally done in closed rooms, (2) traditional games and modern games have character values on the cognitive aspect, Social, emotional and identity, and (3) traditional games accentuate the values of social characters, while modern games accentuate the values of individual characters. The results of the study can be used by educators, especially counselors in schools to make games as a technique in counseling in shaping the character of students.

c. Nafisah (2017) The results of research are known that traditional games of hide and seek and jump rope have a significant influence on the formation of democratic character and discipline.

d. Na'imah \& Septiningsih (2015), the results of research on character education for deaf children are: (1) mildly blind children have problems with low social character and personal character. This is indicated by some of his behavioral problems, namely less independence, lack of responsibility, less able to manage themselves, less able to control themselves, like to fight, speak disrespectfully, do not care to others and like to resist; (2) The methods used in 
character development are to advise, to set examples, to create a pleasant atmosphere, to correct errors of action in a positive way.

e. Rahmadani, Latiana, \& Agustinus (2018) concluded that the influence of traditional games on the development of early motor skills is reviewed from three aspects in traditional "engklek" games, namely: (1) locomotor aspects, consisting of aspects of jumping and jumping. (2) The nonlocomotor aspect consists of standing upright, spinning, rotating by changing, and (3) the manipulative aspect consisting of throwing a gacuk in a box. Three aspects can develop with traditional games, one of which is engklek and can be played physical learning activities at school or daily activities at home with other friends. Introduce to early childhood if Indonesia has many games and traditional cultures in each regional country.

f. Dehkordi (2017) concluded that traditional games are able to maintain physical health, improve spiritual and mental conditions, and develop character, cultural values, national and religious identity.

g. Dubinsky (2010) Research on neuroscience learning has made significant progress for educators with disabilities, sensitive periods and adolescent brain development. These advances should also affect educational approaches, neuroscience touches on many of the issues that affect teaching: learning, stress management, social interaction, and self-image in children. Based on the concept of a previous relevant frame of mind, schema, and research, it can be concluded that there will be optimization of traditional "gobak sodor" game activities based on neuroscience learning as character education in light ATG.

\section{Conclusions}

Optimization of adaptive physical education learning can occur through synergistic contributions through neuroscience learning in traditional games and character education of lightly impaired children. The results of adaptation of these mechanisms are able to reduce the barriers of cognitive domains, practice domains, and social domains of lightly impaired children. Mechanisms centered on the nervous system in the brain, will be able to optimize intelligence and other aspects that are able to improve movement, improve the character of children, and motivate children to routinely do physical activity. So it can be concluded that the traditional game activity "gobak sodor" based on neuroscience learning can be used as an optimization of character education for lightly impaired children. The recommendation of this paper is, it is very interesting if these theoretical findings are continued in the form of future research that tests the truth of this theory.

\section{References}

American Psychiatric Association. (2013). Diagnostic and Statistical Manual of Mental Disorders (DSM-5). American Psychiatric Pub.

Bidaya, Z., \& Rangga, M. (2019). Kajian Yuridis Undang-Undang Nomor 35 Tahun 2014 Tentang Perlindungan Anak dalam Perspektif Pendidikan. CIVICUS: PendidikanPenelitian-Pengabdian Pendidikan Pancasila Dan Kewarganegaraan, 7(2), 48-58.

Burhaein, E. (2017a). Aktivitas Fisik Olahraga untuk Pertumbuhan dan Perkembangan Siswa 
Sports Education Study Program, University of Ma'arif Nahdlatul Ulama Kebumen

SD. Indonesian Journal of Primary Education, 1(1), 51-58. https://doi.org/10.17509/ijpe.v1i1.7497

Burhaein, E. (2017b). Aktivitas Permainan Tradisional Berbasis Neurosainslearning Sebagai Pendidikan Karakter Bagi Anak Tunalaras. Jurnal SPORTIF: Jurnal Penelitian Pembelajaran, 3(1), 55. https://doi.org/10.29407/js_unpgri.v3i1.580

Burhaein, E., Demirci, N., Lourenço, C. C. V., Németh, Z., \& Phytanza, D. T. P. (2021). Coping with the COVID-19 pandemic: the role of physical activity. An international position statement. International Sports Studies, 43(1), 52-70. https://doi.org/10.30819/iss.43-1.05

Burhaein, E., Phytanza, D. T. P., \& Demirci, N. (2020). The development and validation of a revised Friendship Activity Scale and Adjective Checklist for use in the Indonesian Unified Sports program. International Sports Studies, 42(e), 18-28. https://doi.org/10.30819/iss.42-e.03

Burhaein, E., Tarigan, B., Budiana, D., Hendrayana, Y., \& Phytanza, D. T. P. (2021). Physical Activity Level of Students with Disabilities during COVID-19 Pandemic. Jurnal Pendidikan Jasmani Dan Olahraga, 6(2), 19-21. https://doi.org/10.17509/jpjo.v6i2.38547

Dehkordi, M. R. (2017). The educational impact of traditional games: the role of zurkhaneh sport in educating children. International Journal of Science Culture and Sport, 5(3), 134139.

Dubinsky, J. M. (2010). Neuroscience education for prek-12 teachers. J-Neurosci., 30(24), $8057-8060$.

Erniati. (2015). Pembelajaran neurosains dalam pembentukan karakter peserta didik pada pondok pesantren. Hunafa: Jurnal Studi Islamika, 12(1), 43-69.

Ferdy Irawan, Y., \& Limanto, D. (2021). Pengaruh Kecerdasan Emosi dan Kesiapan Diri Terhadap Pertandingan Pada Pemain Walet Muda Futsal Academy Kebumen Tahun 2020. JUMORA: Jurnal Moderasi Olahraga, $1(01), \quad 18-26$. https://doi.org/10.53863/mor.v1i01.130

Fitri, R. (2017). Metakognitif pada Proses Belajar Anak dalam Kajian Neurosains. Jurnal Pendidikan, 2(1), 44-52.

Fraenkel, J. R., Wallen, N. E., \& Hyun, H. H. (2012). How to design and evaluate research in education. New York: Mc Graw Hill.

Guntur Sutopo, W., \& Misno. (2021). Analisis Kecepatan Tendangan Sabit Pada Pesilat Remaja Perguruan Pencak Silat Tri Guna Sakti Di Kabupaten Kebumen Tahun 2020. JUMORA: Jurnal Moderasi Olahraga, 1(01), 27-34. https://doi.org/10.53863/mor.v1i01.131

Guyton, A. C., \& Hall, J. E. (2017). Textbook of Medical Physiology. In Surgical Neurology International (Vol. 8). https://doi.org/10.4103/sni.sni_327_17

Hendrowibowo, L. (2018). Implementasi permainan tradisional sebagai salah satu sarana pendidikan karakter di tk aba, jeruk wudel, gunung kidul. Prosiding Seminar Nasional "Penguatan Pendidikan Karakter Pada Siswa Dalam Menghadapi Tantangan Global," 266-271. 
Hielkema, T., \& Hadders-Algra, M. (2016). Motor and cognitive outcome after specific early lesions of the brain - a systematic review. Developmental Medicine and Child Neurology, 58, 46-52. https://doi.org/10.1111/dmcn.13047

Irman. (2017). Nilai-nilai karakter pada anak dalam permainan tradisionan dan modern. Konseli (Jurnal Bimbingan Dan Konseling), 4(2), 89-96.

Joyce, B., Weil, M., \& Calhoun, E. (2015). Models of teaching (9th Ed). Boston: Pearson.

Kauffman, J. M., \& Hallahan, D. P. (2011). Handbook of special education. New York: Routledge.

Kemendikbud RI. (2016). Konsep Dasar Penguatan Pendidikan Karakter. Jakarta: Kementerian Pendidikan dan Kebudayaan.

Kothari, R., \& Sharma, S. (2019). Sports Physiology - An Upcoming Avenue. Journal of Mahatma Gandhi Institute of Medical Sciences, 24(1), 9-12. https://doi.org/10.4103/jmgims.jmgims

Lonto, A. L. (2019). Pengembangan Model Pendidikan Karakter Berbasis Nilai Sosio-Kultural pada Siswa SMA di Minahasa. Mimbar, 31(2), 319-327.

Mahmood, S. (2021). Instructional Strategies for Online Teaching in COVID-19 Pandemic. Human Behavior and Emerging Technologies, 3(1), 199-203. https://doi.org/10.1002/hbe2.218

Metzler, M. W. (2017). Instructional models in physical education (3rd Ed). https://doi.org/https://doi.org/10.4324/9781315213521

Molbaek, M. (2018). Inclusive teaching strategies-dimensions and agendas. International Journal of Inclusive Education, 22(10), 1048-1061. https://doi.org/10.1080/13603116.2017.1414578

Mustofa, F., Mansur, M., \& Burhaein, E. (2019). Differences in the effect of learning methods massed practice throwing and distributed distributed practice on learning outcomes skills for the accuracy of top softball. Journal of Sport Sciences Researches, 4(2), 213-222. https://doi.org/10.25307/jssr.571793

Na'imah, T., \& Septiningsih, D. S. (2015). Pendidikan karakter untuk anak berkebutuhan khusus (studi relasi gender pada keluarga yang memiliki anak tuna grahita ringan). Prosiding Seminar Nasional Penelitian Dan PKM Kesehatan, 239-246.

Nafisah, W. (2017). Pengaruh permainan tradisional petak umpet dan lompat tali terhadap pembentukan karakter demokratis dan disiplin anak usia sekolah dasar di SDN Pakukerto 1 Sukorejo Kabupaten Pasuruan. UIN Maulana Maling Ibrahim Malang.

Phytanza, D. T. P., \& Burhaein, E. (2020). The Effects of Tenure, Teacher Certification, and Work Motivation on Special Needs Teacher Performance. Universal Journal of Educational Research, 8(9), 4348-4356. https://doi.org/10.13189/ujer.2020.080962

Phytanza, D. T. P., Burhaein, E., \& Pavlovic, R. (2021). Gross Motor Skills Levels in Children with Autism Spectrum Disorder during the COVID-19 Pandemic. International Journal of Human Movement and Sports Sciences, 9(4), 738-745. 
Sports Education Study Program, University of Ma'arif Nahdlatul Ulama Kebumen https://doi.org/10.13189/saj.2021.090418

Pramantik, I. A. D., \& Burhaein, E. (2019). A Floor Time Approach to Improve Learning Outcomes of the Body Roll to the Side in Adaptive Physical Education Learning: Classroom Action Research Study on Two Cerebral Palsy Students. International Journal of Disabilities Sports and Health Sciences, 2(2), 45-53. https://doi.org/10.33438/ijdshs.652061

Prasetyo Widiyono, I., \& Mudiono. (2021). Keterampilan Dasar Futsal Peserta Ektrakurikuler di SMK Ma'arif 1 Kebumen Tahun Ajaran 2019/2020. JUMORA: Jurnal Moderasi Olahraga, 1(01), 10-17. https://doi.org/10.53863/mor.v1i01.129

Rahmadani, N. K. A., Latiana, L., \& Agustinus, R. A. E. N. (2018). The influence of traditional games on the development of children's basic motor skills. Advances in Social Science, Education and Humanities Research (ASSEHR), 192(1), 160-163. Retrieved from https://jurnalmahasiswa.unesa.ac.id/index.php/Commercium/article/view/25236/23126

Rizqi Azizah, A., \& Pujo Sudarto, E. (2021). Minat Mengikuti Ekstrakurikuler Bola Voli Siswa Smp Negeri 3 Satu Atap Karangsambung Kecamatan Karangsambung Tahun Ajaran 2019/2020. JUMORA: Jurnal Moderasi Olahraga, 1(01), 35-44. https://doi.org/10.53863/mor.v1i01.132

Saputri, N., \& Suharjana. (2020). Development of hockey game and model for learning physical education in children's elementary school. Acta Facultatis Educationis Physicae Universitatis Comenianae, 60(November), 133-145. https://doi.org/10.2478/afepuc-20200011

Schunk, D. H. (2014). Learning theories: an educational perspective. London: Pearson.

Suherman, A. (2018). The Implementation Of Character Education Values In Integrated Physical Education Subject In Elementary School. SHS Web of Conferences, 42(1), 1-6. https://doi.org/https://doi.org/10.1051/shsconf/20184200045

Widodo, P., \& Najibuzzamzam, A. (2021). Perbandingan Model Pembelajaran Daring Dan Tatap Muka Penjaskes Mts Darussa'adah Pada Masa Pandemi Tahun Ajaran 2019/2020. JUMORA: Jurnal Moderasi Olahraga, $\quad 1(01), \quad 1-9$. https://doi.org/10.53863/mor.v1i01.128 